\title{
THE PSYCHOLOGICAL AND HISTORICAL PERSPECTIVE BEHIND ENTREPRENEURIAL AND BUSINESS PRACTICES IN INDONESIA
}

\author{
Muhammad Asif Khan \\ Bina Nusantara University, Indonesia. \\ Corresponding Author: Muhammad.khan001@binus.ac.id
}

\begin{tabular}{l} 
ARTICLE INFO \\
\hline Article History: \\
Received: March 30, 2020 \\
Revised: July 20, 2020 \\
Published Online: August 17, 2020 \\
Keywords: \\
Psychological perspective, Historical \\
perspective, Business Practices, \\
Entrepreneurship, \\
Indonesia.
\end{tabular}

How to cite:

Khan, M. A. (2020). The Psychology and Historical Perspective behind Entrepreneurial and Business Practices in Indonesia. International Journal of Digital Entrepreneurship and Business (IDEB), 1(1), 30 - 36.

\begin{abstract}
Indonesia is a country in southern Asia consisting of many islands and is the $4^{\text {th }}$ largest populated country in the world. The country has one of the best economies in the world since it has been participating in international trade for many years. However, it has had drawbacks that have made it unable to reach the levels of the developed countries in the world. Therefore, it is necessary to study the facts behind the success and the failure of some business ventures. Additionally, the study of strategies by companies to have a competitive advantage in business is fundamental to understanding the situation in the country. The new research will seek to use the available analyses about the same topic to bring about a new understanding. Theories such as McClelland's locus of control theory can apply in the study to understand the relationship between entrepreneurship and the psychology of people. The paper uses secondary sources review to get information about the topic to propose a solution to the challenges that the companies in the country have been facing towards achieving a competitive returns.
\end{abstract}

\section{INTRODUCTION}

Indonesia has had a thriving business culture, ahead of many countries in the world. The people of Indonesia understand the culture and psychology of development and pass the same ideas from one generation to another. Indonesia is one of the speedily developing countries in Asia and enjoys international markets in many countries that import and export their product from and into the country, respectively (Meutia \& Putra, 2017). Many scholars have been seeking to understand the psychology and history behind the success of business in this country. The nation captures the attention of many people since it attained independence in 1945, many years after most countries in the world had already developed and industrialized. Some of the traditions in the Indonesian culture helps the business to establish since the people use the cultural norms that exist in Indonesian societies in the workplace. Consequently, there is a need to create whether the psychological and historical nature of the country helps to develop in terms of business and organizations. The paper seeks to identify the psychological and historical perspective behind the success of the business culture in Indonesia.

Many researchers have established much about the country of Indonesia. However, the researchers have not yet developed whether psychology is part of the factors that make the nation prosper in business more than other countries in the region and the world. Therefore, the current research will establish the psychological aspects that cause people to engage their minds in the business to the extent that they beat other companies around the world in production. Psychology concerns the mind of a person and how they behave in their daily actions. Therefore, the people of Indonesia rely on the activities established by the relationships of people many years ago (Kuntoro et al., 2017). The history of the behavior of people has conditioned the actions of people in the organizations and the general business field. History 
has played a significant role in making sure that the people have remained on course in their business practices. The historical perspectives always remind people about what the people in the past used to do in business (Malik \& Handono, 2019). The study will connect the psychology of people, the historical aspects, and views about business practices in the country.

Researchers have been working on understanding multiple aspects about the Indonesian business culture. Some of the initiatives that have prompted these steps in academia are the successful business development in the country, the high rate of growth in the country, and the thriving business culture. Consequently, there is a need to establish the factors that are behind the success of business practices in the country. Psychology involves the understanding of people's minds concerning their behaviors (Perneger, 2004). Therefore, there is a need to understand the business psychology before establishing whether psychology is part of the factors that help companies in Indonesia to thrive. Historical perspectives also play leading roles in the success of business practices in the country (Maringka \& Rahmani, 2017). Therefore, the research will dwell into some of the aspects that entrepreneurs rely on to make decisions within an organizations in Indonesia.

Research questions in this paper would streamline the direction in which this particular research will follow. The paper also includes the novelty describing the new concepts that the previous researchers failed to identify. Theoretical approaches are a representation of the theories that can be applied in the research. The methodology used in this paper uses secondary sources to establish the concepts discussed. Finally, the paper proposes a solution to discuss the challenges faced by the Indonesian companies.

The aim of this paper is to explore and reveal the function of psychological perspective behind business practices within Indonesian context with the aim of exploring the native perspective. The paper uses secondary sources to obtain information on the topic in order to propose a solution to the challenges faced by the companies in the country to achieve a competitive advantage. Additionally data is gathered through document review, therefore findings are carried out on the basis of prior research in business and management practices in Indonesian industry, providing crucial meaning to an evaluated subject (Bowen , 2009).

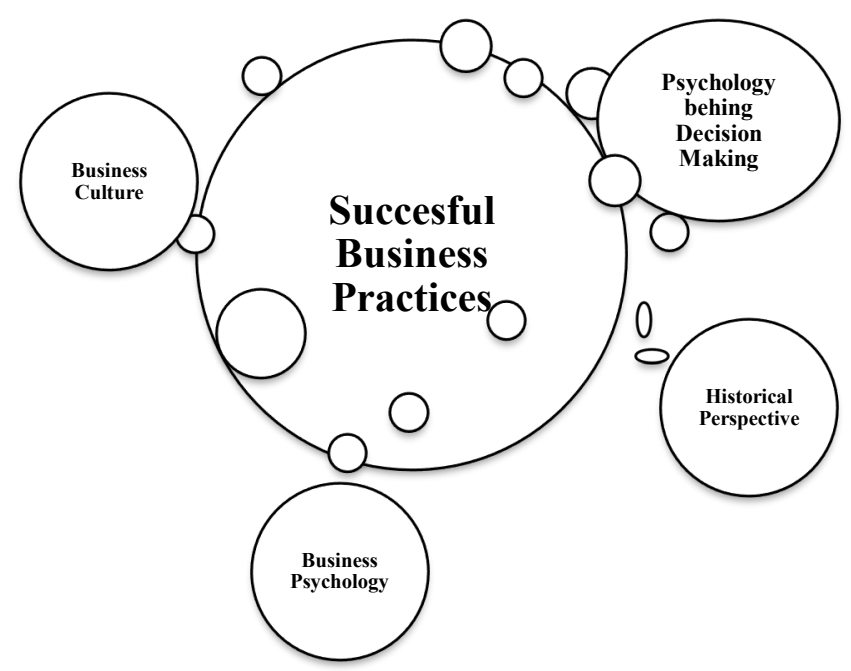

Figure 1: Current Research Framework.

The paper will answer the following research questions:

1. What are the psychological and historical perspectives behind the success and failure of business practices in Indonesia?

2. What are the appropriate strategies that help to create a competitive advantage for Indonesian businesses? 


\section{LITRATURE REVIEW}

Maulana et al. (2018) have done a qualitative study on the Indonesian population to establish the wellbeing of the people of Indonesia. The study involved an understanding of the activities of Indonesians by investigating different generations of people to develop the aspects of wellbeing. The elements of prosperity, such as the basic needs, relationships in the families and communities, selfacceptance, and spirituality, constitute the people of Indonesia. The article can help in understanding the characteristics of the Indonesia people as it covers most things that concern people in the country.

A country that focuses on fulfilling the basic needs of people can easily depend on developed companies to provide the requirements to its people (Hendar et al., 2017). Indonesian communities and families seems to have well-established relationships to develop their country by taking part in the activities that help each member of the community. The country has a spiritual culture in which people are religious and believe that they can fulfill their souls by working hard in life to remain successful. Consequently, the sources provide a basis for the study of the psychological perspective of the success of the organizations in Indonesia.

Nevertheless, the determinants of the decision to become an entrepreneur were not yet accepted by social scientists, thus early work centered only on psychological characteristics and human attributes, acting as an antecedents of new venture development and their success. In addition, most researchers discuss education systems, socio-cultural and economic influences as having a significant impact on the growth of a particular society's entrepreneurial behavior (Ahamed \& Rokhman, 2015). Cunningham and Lischeron (1991) points out, "if we want to understand the mechanism of entrepreneurship, we need to consider the individual role in triggering the mechanism. The associations between these variables were not systematically examined to the best of our knowledge, not to mention that the associated results were also heterogeneous and incoherent". More significantly, it could be misleading to concentrate only on entrepreneurial qualities, when more proximal characteristics are overlooked (Gartner, 1989). An entrepreneur is an individual with high ambiguity tolerance (Koh, 1996; Sexton \& Boman, 1985). He or she is able to take on the unknown, anxious to try out, and control confusion (Acedo \& Jones, 2007). Entrepreneurs tend to be more tolerant of uncertainty than non-entrepreneurs (Sexton \& Bowman, 1985). Many facets of entrepreneurship proved to be predictors of personality traits (Shaver \& Scott, 1991).

Characteristics of personality, known as trait theory, contribute to entrepreneurs' personal characteristics. Personality characteristics were divided into a few categories: first, requires achievement. McClelland's need for achievement theory demonstrated that one of the main psychological factors affecting entrepreneurial behavior is the need for achievement. Individuals with a high need for achievement have a deep incentive to succeed, and are more likely to be entrepreneurs. McClelland (1961) suggested that individuals with a strong need for achievement are more likely to solve issues on their own, set challenging goals and strive to achieve them through their own efforts. Highly-needed individuals will contribute more to entrepreneurship (Tong, Tong \& Loy, 2011). In challenging tasks they are able to perform better and to discover innovative ways to improve their performance (Littunen, 2000). The study conducted by Tong et al. ( 2011) suggests that the need for achievement is the strongest predictor of entrepreneurial intent. Kaijun and Sholihah (2015) concluded that entrepreneur who have entrepreneurial intentions are more confidence and are able to understand business obstacles as they may arise.

Muluk et al. (2018) points out that the psychology of the people of Indonesia is still in development. In essence, they point out the fact that the country has been depending on western perspectives. However, the people have since transformed into working with indigenous psychological aspects that have made them establish an influential culture in the country (Echdar, 2015). The study suggests that Indonesian business psychology still depends on historical views since most communities have not come up with modern ways of solving or explaining some phenomena. The article is significant in this paper since it provides grounds for the psychological perspectives of the people of Indonesia. The authors proposed that future scholars should seek to understand the new psychological aspects that are free from the old 
thoughts and beliefs of the people. Therefore, Muluk et al. (2018) articulated the psychological explanation of the success of the companies in Indonesia.

Indonesian bureaucracies are normally pinnacle heavy, while a legit decision-making edifice exists which allows for decisions to be made at lower level, which in reality hardly takes place. Foreign investors new to Indonesia are frequently amazed by way of the reality that the most effective license, permit or application must be permitted by the top echelons of a government corporations, ministry which takes a long term for even the decision to be made (Norway, 2017).

Most entrepreneurs in the world have theories on which they base their business ideas. Most of the arguments came from scholars who studied the field years ago and applied at different times in the same field. One of the theories that have existed in the area of business for a long time is McClelland's theory that is also called the achievement motivation theory (Bhattacharjee \& Chetty, 2019). With this theory, the target achievement of the entrepreneurs directs their actions within the business practices. Gartner (1990) noticed the lack of a common core or definition of the area, in an effort to describe entrepreneurship, conducted a Delphi survey of scholars, business leaders and policymakers.

There was no common concept, but eight themes emerged: the entrepreneur, creativity, development of organizations, value creation, and profit versus nonprofit, prosperity, uniqueness, and the ownermanager. As seen above, most early academic work on entrepreneurship concentrated on personal characteristics as well as individual entrepreneurs and firms' success or failure, largely as a result of psychology and sociology-based research. Organizational sociologists have focused on firms' populations when considering success and failures in corporations (Cooper \& Anderson, 2005). Once economists were eventually engaged, the scope of the study widened but there was no consensus on the field boundaries.

The study source on individuals and teams is deeply rooted in behavioral science and focuses on the individual entrepreneurs' 'intrapersonal' processes, which includes the knowledge of culture, identity, behavior, and self-determination. Cognitive biases and heuristics, and attribute concepts are the social cognition mechanisms that have gained the greatest attention in entrepreneurship. In the literature on social psychology, 'attribution' refers to the cognitive mechanisms by which people justify their own behavior, other's acts, and world events. The work which provided the basis for the theory of attribution is by Heider (1958), who argued that behavior is a feature of both the individual and the external environment (Mikulincer \& Shaver, 2003). McClelland (1961) tried to incorporate psychological and sociological reasons for economic growth and decline. He described entrepreneurship as one of four main factors along with technology, population growth, and division of labor enabling economic development.

The goals of organizations in companies with the state have a profound impact on the way people work in organizations. McClelland (1961) explained that the achievement that an entrepreneur thinks of having after a particular period makes them plan on priorities in the companies. The theory plays a leading role in the companies within the boundaries of Indonesia since the companies have set limits on what to achieve within specific time frames. Another approach that entrepreneurs use in the establishment of their services is the Rotter's locus of control theory. The theory has two aspects of a high internal locus of control and a high external locus of control. Entrepreneurs in Indonesia should focus on the internal locus in which the outcome depends on the actions of the individuals in various companies. Therefore, the population of the country depends on the hard work of every individual, resulting in massive production in the organizations.

Previous researches involved many people in the entrepreneurship industry in establishing the fact behind the success of the companies in the country. The experience of the people who participate in the companies is detrimental to the company's results in that country (Huang et al., 2015). This paper has employed the use of secondary sources of literature to establish the facts behind the success of 
companies in Indonesia. For these sources, it is fundamental to create the fact that many people have researched the organizational plans in the country since many investors wish to understand the business plans and the behavior of people in the organizations in the country. People have been seeking to understand the culture of the country, while others have been trying to establish the psychological concept behind the organizational success of companies in the country (Hermawan \& Loo, 2019). Therefore, it is significant for now to note that the culture of the communities in the country has been playing leading roles in making sure that the people take part in the development of their companies. Additionally, scholars have also established that psychology has also been instrumental in the economic development of Indonesia.

\section{ANALYSIS AND DISCUSSION}

Indonesia the $4^{\text {th }}$ largest populated country in the world has not realized the application and implication of the modern psychological perspectives in business and organizations. Many scholars have carried out studies on Indonesian people to understand their behavior in their perspective industry. Many people understand that Indonesia is one of the rapidly growing countries (Blesia, 2017). However, there is much to understand why the state has not reached the level of success that countries like United States and China enjoy. Additionally, studies have established that people feel that the history of their country has long-lasting effects on the economy of the nation. The companies in the country, however, are always on the run to ensure that the production is as per the requirement of the population to keep the economy of the country moving and to create a competitive advantage in the business world at the international level.

The businesses in Indonesia have been thriving in the past years since it's' independence in 1945. However, Indonesia is facing leadership challenges like many other countries (Dingliana, 2019). Most countries have been having problems in establishing strong economies because of the difficulties they face in politics. Therefore, Indonesia has had regimes, some of which have affected the country's growth in business. State fails to compete favorably with nations such as China and the United States of America because of the psychological and historical perspectives within its population. Indonesians need to study the modern psychological understanding of entrepreneurship to establish the competitive advantage that the current market needs (Belenzon \& Tsolmon, 2015). Many people in the country should leave the old ways of thinking when it comes to business and uses modern theoretical analyses to understand the direction of the advances in business and organizations.

\section{CONCLUSION}

Indonesia is among the largest countries in the world and the countries with developed companies and organizations. However, the psychological perspectives in the country seem to make it fail to reach the success it deserves. Many entrepreneurs have not involved psychological and historical behavior in the companies and the workers to make sure that they improve on production. Additionally, the history of the country has affected its development. For instance, the country got independence in 1945, many years after many countries in the world had attained its independence. Despite the challenges, the companies in the country have been thriving, providing the state with much-needed production. Such companies have endured challenges in the political arena and the inflation in the markets over the years. The people of Indonesia need to have strategies that can make the country to have a competitive advantage in the world since many countries are developing.

The study can apply in many situations in the field of business. Many countries are going through challenges that might be similar to those of Indonesia. Therefore, the study of the problems affecting the state of Indonesia and how the people are trying to solve the issue can make it easy to use this study to apply in these countries. The study can help investors in the world to understand the countries in which they need to invest their capital. Having an analysis of the psychological perspectives of a particular group of people can help a researcher to understand the ideologies of such groups. The study can apply to academics for students who want to study various aspects of economic development in the world. Students from different faculties such as economics, psychology, and political science can find this article useful in their studies. Therefore, the study is applicable in many aspects of life as it has 
touched on various ideas.

\section{REFERENCES}

Acedo, F.J. and Jones, M.V. (2007) Speed of Internationalization and Entrepreneurial Cognition: Insights and a Comparison between International New Ventures, Exporters and Domestic Firms. Journal of World Business, 42, 236-252.http://dx.doi.org/10.1016/j.jwb.2007.04.012

Ahamed, F., \& Rokhman, W. (2015). The Role of Social and Psychological Factors on Entrepreneurial Intention among Islamic College Students in Indonesia. Entrepreneurial Business and Economics Review, 3(Vol. 3 No. 1), 29-41.

Belenzon, S., \& Tsolmon, U. (2015). Market Frictions and the Competitive Advantage of Internal Labor Markets. Strategic Management Journal, 37(7), 1280-1303. https://doi.org/10.1002/smj.2395

Bhattacharjee, J., \& Chetty, P. (2019). Psychological Theories of Entrepreneurship. Retrieved 28 March 2020, from https://www.projectguru.in/psychological-theories-entrepreneurship/.

Blesia, J. (2017). Culture and Accounting Practices in Indonesia. Asian Journal of Economics, Business, And Accounting, 4(4), 1-11. https://doi.org/10.9734/ajeba/2017/36846

Bowen, G.A. (2009). Document Analysis as a Qualitative Research Method. Qualitative Research Journal, Vol. 9 No. 2, pp. 27-40. https://doi.org/10.3316/QRJ0902027

Cooper-Thomas, H.D. \& Anderson, N. (2005), Organizational Socialization: A Field Study into Socialization Success and Rate. International Journal of Selection and Assessment, Vol. 13 No. 2, pp. 116-28.

Cunningham, J. \& Lischeron, Joe. (1991). Defining Entrepreneurship. Journal of Small Business Management. 29. 45-62.

Dingliana, S. (2019). Continuity in Indigenous Family Businesses: A Study of Succession in Mizo Family Businesses. The SIJ Transactions on Industrial, Financial \& Business Management, 07(02), 07-11. https://doi.org/10.9756/sijifbm/v7i2/0102630102

Echdar, S. (2015). Human Capital Development Strategy on Go-Public Manufacturing Companies in Indonesia. Journal of Economics, Business \& Accountancy Ventura, 18(1), 103. https://doi.org/10.14414/jebav.v18i1.387.

Gartner, W. B. (1989). "Who is an Entrepreneur?" is the Wrong Question. Entrepreneurship Theory and Practice, 13, 47-68.

Gartner, W. (1990). What are we talking about when we talk about Entrepreneurship? The Journal of Business Venturing, 5, 15-25. Journal of Business Venturing. 5. 15-28. 10.1016/08839026(90)90023-M.

Hendar, H., Ferdinand, A., \& Nurhayati, T. (2017). Introducing the Religio-Centric Positional Advantage to Indonesian Small Businesses. Management \& Marketing, 12(1), 78-102. https://doi.org/10.1515/mmcks-2017-0006

Heider, F. (1958). The Psychology of Interpersonal Relations. New York: John Wiley \& Sons. http://dx.doi.org/10.1037/10628-000

Hermawan, M., \& Loo, M. (2019). The Construction of Kekeluargaan as Indonesia's Organizational Culture. Jurnal Humaniora, 31(1), 1. https://doi.org/10.22146/jh.v31i1.42851

Huang, K., Dyerson, R., Wu, L., \& Harindranath, G. (2015). From Temporary Competitive Advantage to Sustainable Competitive Advantage. British Journal of Management, 26(4), 617-636. https://doi.org/10.1111/1467-8551.12104.

Kaijun, Yang \& Sholihah, Puput. (2015). A Comparative Study of The Indonesia and Chinese Educative Systems Concerning the Dominant Incentives to Entrepreneurial Spirit (Desire for a New Venturing) of Business School Students. Journal of Innovation and Entrepreneurship. 4. 10.1186/s13731-0140014-0.

Koh, H.C. (1996). Testing Hypotheses of Entrepreneurial Characteristics. Journal of Managerial Psychology, 11, pp.12-25.

Kuntoro, I., Peterson, C., \& Slaughter, V. (2017). Culture, Parenting, and Children's Theory of Mind Development in Indonesia. Journal Of Cross-Cultural Psychology, 48(9), 1389-1409. https://doi.org/10.1177/0022022117725404. 
Littunen, H. (2000). Entrepreneurship and the Characteristics of the Entrepreneurial Personality. International Journal of Entrepreneurial Behavior \& Research, 6(6), 295-309.

Malik, A., \& Handono, W. (2019). Financial Performance Analysis of SOE and Foreign Capital Cement Companies in Indonesia. People: International Journal of Social Sciences, 5(1), 267-294. https://doi.org/10.20319/pijss.2019.51.267294

Maringka, J., \& Rahmani, N. (2017). Ethical Business Cultures in Indonesia. Ethical Business Cultures in Emerging Markets. https://doi.org/10.1017/9781316225165.011

Maulana, H., Obst, P., \& Khawaja, N. (2018). Indonesian Perspective of Wellbeing: A Qualitative Study. The Qualitative Report, 23(12), 3136-3152. Retrieved from https://nsuworks.nova.edu/tqr/vol23/iss12/18.

McClelland, David C., The Achieving Society (1961). University of Illinois at Urbana-Champaign's Academy for Entrepreneurial Leadership Historical Research Reference in Entrepreneurship, Available at SSRN: https://ssrn.com/abstract=1496181

Meutia, I., \& Putra, B. (2017). Narrative Accounting Practices in Indonesia Companies. Binus Business Review, 8(1), 77. https://doi.org/10.21512/bbr.v8i1.1944

Mikulincer, M., \& Shaver, P. R. (2003). The Attachment Behavioral System in Adulthood: Activation, Psychodynamics, and Interpersonal Processes. Advances in Experimental Social Psychology, 35, 53152. https://doi.org/10.1016/S0065-2601(03)01002-5

Muluk, H., Hudiyana, J., \& Shadiqi, M. (2018). The development of Psychology of Culture in Indonesia. Asia-Pacific Perspectives on Intercultural Psychology, 140-156. https://doi.org/10.4324/9781315158358-8

Norway, I. (2017). Challenges of Doing Business in Indonesia. Norwagian Energy Partners, 7-57.

Perneger, T. (2004). Writing a Research Article: Advice to Beginners. International Journal for Quality in Health Care, 16(3), 191-192. https://doi.org/10.1093/intqhe/mzh053

Shaver, K. G. \& Scott, L. R. (1991). Person, Process, Choice: the Psychology of New Venture Creation. Entrepreneurship. Theory and Practice, 16(2), 23-45.

Sexton, D.L. and Bowman, N. (1985). The Entrepreneur: A Capable Executive and More. Journal of Business Venturing, Vol. 1, pp. 129-40.

Tong, X.F., Tong, D.Y.K., \& Loy, L.C. (2011). Factors Influencing Entrepreneurial Intentions among University Students. International Journal of Social Sciences and Humanity Studies, 3(1), 487-496 